\title{
Typology and physical-chemical characterization of bovine milk produced with different productions strategies
}

\author{
A.M. Gabbi ${ }^{\text {a }}$, C.M. McManus ${ }^{\text {a }}$, A.V. Silva ${ }^{\text {b }}$, L.T. Marques ${ }^{c}$, M.B. Zanela ${ }^{\text {d }}$, M.P. Stumpf ${ }^{\text {a }}$, V. Fischer ${ }^{\text {a,* }}$ \\ ${ }^{a}$ Department of Animal Science, Universidade Federal do Rio Grande do Sul, Porto Alegre, RS, Brazil \\ ${ }^{\mathrm{b}}$ Universidade Federal do Rio Grande do Sul, Porto Alegre, RS, Brazil \\ ${ }^{\mathrm{c}}$ Universidade Federal de Pelotas, Pelotas, RS, Brazil \\ ${ }^{\mathrm{d}}$ Centro Nacional de Pesquisa de Clima Temperado, Empresa Brasileira de Pesquisa Agropecuária, Pelotas, RS, Brazil
}

\section{A R T I C L E I N F O}

\section{Article history:}

Received 26 November 2012

Accepted 26 July 2013

Available online 19 August 2013

\section{Keywords:}

Clusters

Principal factors

Milk composition

Milk production

Milk quality

Productions systems

\begin{abstract}
A B S T R A C T
In the tropics, milk production systems present high diversity and distinct ability to adapt to the demands of consumers and market conditions. Knowledge of the factors that affect the quality of milk and agglomerate of production systems into fewer groups can facilitate analysis and the decisions needed to improve them. The objective of this paper was to characterize, classify and analyze dairy production systems in the Brazilian southern region, and relate their productive aspects to the physical-chemical attributes of the milk produced. A multivariate analysis was conducted with 26 indicators obtained from a survey covering 328 dairy farms. Variance was fully explained by the first three principal factors. The first factor included feeding strategies, the second included the farm's structure traits and the third included milk composition. Canonical analysis revealed distribution of farmers into three clusters. All feeding strategies, except salt supplementation, as well as monthly milk production, herd size, number of lactating cows in farm and unstable milk frequency were important discriminant variables to determinate cluster formation. The clusters were differentiated by feeding strategies used and the high standard deviation in some of these strategies demonstrated the adoption of specific strategies in different seasons. Cluster 3 had the largest monthly milk production and larger number of lactating cows, but the productivity of cows in the different clusters was not significantly different. The lower unstable milk frequency in cluster 3 is associated with more intensive use of silage, mineral-vitamin premix and commercial concentrate in the diet of animals. The physical-chemical composition of milk and the somatic cell count did not differ between clusters.
\end{abstract}

(c) 2013 Elsevier Ltd. All rights reserved.

\section{Introduction}

Milk is produced in Brazil throughout the national territory, in approximately 1,340,897 farms (IBGE, 2007) and it presents a high degree of diversity in terms of their characteristics, with scales and levels of expertise varying from a low input extractive manner to the adoption of a highly intensive dairy business posture (Mancio et al., 1999; Lopes et al., 2007). Typification of these producers may occur considering a variety of features analyzed in each production system (Bodenmüller Filho et al., 2010). Herd size, area for milk production, milking practices, cooling milk procedures, feed management and type of food used may aid in characterizing the producers evaluated. As well as natural and individual variability (Tsioulpas et al., 2007), milk physical and chemical properties may be altered by a several factors related to the characteristics

* Corresponding author. Address: Programa de Pós-Graduação em Zootecnia, Faculdade de Agronomia, UFRGS, Av. Bento Gonçalves, 7712, Porto Alegre 91540000, RS, Brazil. Tel.: +55 51 33086027; fax: +55 5133086048 .

E-mail address: vfried@portoweb.com.br (V. Fischer). of the production systems, such as feeding practices, microbial contamination due to sanitary, milking and cooling practices (Smith et al., 2002; Wagner et al., 2004). Characterization and classification of dairy farms according to their productive characteristics might highlight the diversity among production systems and their products, facilitate comparison among the groups and may help to provide technical support to improve their sustainability (Smith et al., 2002; Ruiz et al., 2009).

This study aimed to characterize, classify and analyze dairy systems in the Brazilian southern region, and relate their productive aspects to the physical-chemical attributes of the milk produced.

\section{Materials and methods}

\subsection{Data}

The present survey was conducted with the consent of the technical department of the dairy industry which collected milk in the southern region of RS. Three hundred and twenty-eight dairy farms 
from six counties of the Rio Grande do Sul state, in the southern region of Brazil were randomly selected. The common feature of all these farms was that they belonged to the same dairy basin and sold their milk to the same dairy industry. Individual farmers were selected to be representative of the production systems and production scale usually observed in this basin. They covered the whole range from very extensive production systems with almost no feed supplementation, use of natural range pasture and crossbred cows and manual milking to feedlot cows, with balanced total mixed diet, pure dairy breed cows, herringbone milking parlor and cooling facilities. Monthly milk productions ranged from 231 to $10,000 \mathrm{~kg}$. Bulk raw milk was sampled monthly on all the farms during 36 months. A questionnaire was sent to the farmers and based on these data we obtained a total of 40 indicators, of which 26 were chosen from PROC FREQ analysis, when cumulative percent of the herd characteristic in question was less than $90 \%$. These variables were grouped into five categories: scale of production, milking procedures, milk cooling systems, feeding and milk attributes. Data used refer to a complete three years period, namely 2002-2005. The following indicators were used to refer to the scale of production: total land area, herd size and number of lactating cows; milking practices: type, udder cleaning and drying, dipping, clinical and sub clinical mastitis tests, cooling systems: type of equipment used; feed used as silage, stover, range pasture, cold season pastures, warm season pastures, hay, home-made concentrate, limestone, salt, premix; milk attributes: monthly production, daily production per cow, crude protein, fat, lactose, unstable milk frequency and somatic cell count (SCC).

\subsection{Statistical procedure}

Analysis of principal factors (PROC FACTOR) was carried out with 18 indicators, and option msa used in statistical procedure to choose variables, mainly feeds used, milk production, milk productivity, herd size and milk physical-chemical attributes and SCC. Multiple and canonical analysis were performed to complement the former analysis. Cluster analysis was performed to group the farms and multiple analysis of variance was conducted to determine the attributes which present statistical differences among the groups.

Data were submitted to statistical procedures PROC FREQ, PROC CORRESP (mca), PROC FACTOR (method $=\mathrm{ml}$, factor number $=3$, msa, matrix rotation = varimax), PROC DISCRIM, PROC STEPDISC, PROC CANDISC, PROC FASTCLUS (iteration maximum number $=10$, 4 clusters with delete $=1$ for few observations), PROC CLUSTER and PROC TREE. These procedures were used for the distribution of data classes, the identification of principal factors, multiple correspondence analysis and the formation of clusters (groups). For comparison between clusters formed, a multivariate analysis (MANOVA) was carried out in PROC GLM. To avoid the use of missing values in analysis of data NOMISS option in PROC FASTCLUS was used. Thus, of the 328 total observations in the survey, 214 were used in the data analysis. SAS for Windows 9.0 (SAS Institute, 2002) was the statistical software used in this study.

\section{Results}

Descriptive statistics of the raw data revealed that from the 328 dairy farms, $87 \%$ of the farmers had low level of formal education as they studied until the fifth school grade, $90 \%$ of the farms are small as they presented total surface area of up 50 ha, $95 \%$ of them had small herds with less than 50 animals, and $46 \%$ of the herds were composed by predominantly dairy breeds (Holstein and Jersey). Milking was done manually in $64.7 \%$ of the farms. Most of the farmers (75\%) had another economic activity besides milk production, and in $92 \%$ of the farms the owners were the responsible for milking. Feeding practices were highly diversified, but it could be noticed that in more than $80 \%$ of the farms, cultivated warm and cold season pastures were used, decreasing to $67 \%$ and $46 \%$ that used, respectively, natural range pasture and silage. A huge variability in the types of concentrates offered to the animals was also noticed, since homemade concentrate ( $23 \%$ of farms), single ingredients for energy or protein supplementation ( $69.4 \%$ of farms) and also formulated commercial concentrate ( $10.6 \%$ of farms). Besides, mineral supplementation as salt, vitamin-mineral and limestone was used by approximately $78 \%, 30 \%$ and $33 \%$ of farmers, respectively.

Feeding practices such as use of natural range pasture, salt and home-made concentrate were associated with higher milk fat content and somatic cell count (SCC) and lower values for titrable acidity, protein and lactose. However those feeding practices were weakly associated with larger herds and milk yield, which in turn were positively related to supplementation with vitamin-mineral, limestone and silage. Feeds with high fiber content as warm season pasture and stover were positively related to milk fat content, while silage, concentrate, salt and natural range pasture were negatively related to milk lactose and protein contents. Larger herds showed milk with lower unstable milk frequency. These relationships can be seen graphically using principal factors, where the first of two factors explained $86.8 \%$ of the total de variation (Fig. 1). Comparing the quadrants divided by the $x$-axis, there is a direct relationship between monthly production of milk, herd size and number of lactating cows with feeding strategies that improve milk production. Moreover, fibrous feeds and milk quality indicators are related to the reverse order with the previously mentioned variables. The variables of chemical composition of milk as lactose and fat have relationships usually described in the literature, with acidity and somatic cell count inversely related to lactose and fibrous feeds directly related to the lipid fraction of milk.

The partial correlation coefficients between original variables and the principal factors (PF) (data not shown) indicated that the variables that most influenced the PF1, PF2 and PF3 were, respectively, feeds used in dairy farms (PF1 = feeding strategies), variables regarding the structure of dairy farm: total area, total number of animals and monthly production of milk (PF2 = scale of production) and variables related to milk composition: acidity, fat and protein concentrations (PF3 = milk composition), demonstrating the importance of feed management and secondarily the scale of production characteristics of farms in explaining the differences between dairy production systems. However, milk characteristics, as they are influenced by several factors, which might present counterbalance effects, did not contribute so significantly in the differentiation of dairy farms.

The canonical analysis of the data (Fig. 2) indicates that the first canonical variable differentiated clusters 1 and 2, while the second canonical variable differentiates these clusters with cluster 3. Although randomly distributed through the clusters formed, milk protein, unstable milk frequency and daily milk production are closed with cluster 1 . Cluster 3 congregated observations associated with lactose, number of lactating cows, monthly production of milk, herd size and milk fat. The other variables were associated with observations grouped into cluster 2 .

Discriminant analysis revealed that feeding practices, number of lactating cows, monthly milk production, unstable milk frequency and herd size were the most important traits in differentiating between farms (Table 1). In the multivariate analysis, the probability values for Wilks' Lambda and the average square canonical correlation (ASCC) were highly significant $(P<0.0001)$ for all variables. In $\mathrm{F}$ test, all variables classified in the discriminant analysis were significantly different.

Following cluster analysis, observations were grouped into three subsets. Table 2 shows the descriptive statistics of farm's 


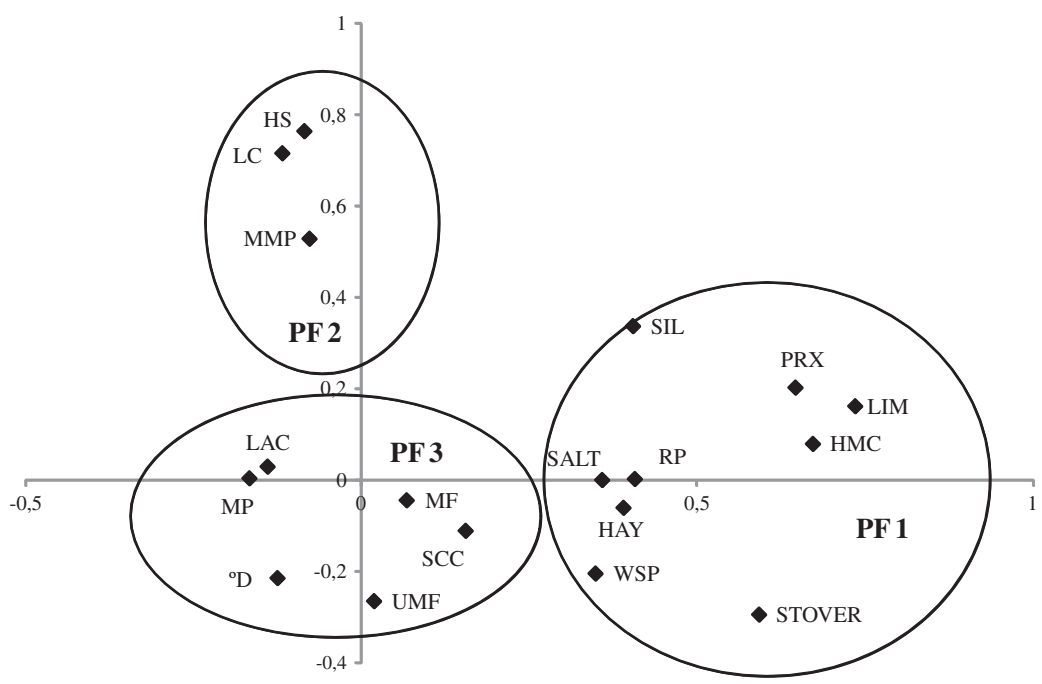

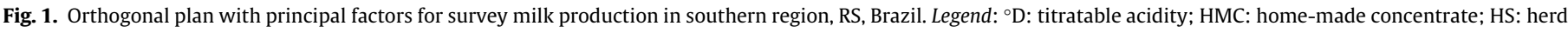

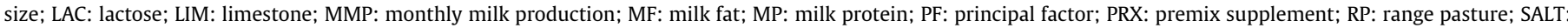
salt; SCC: somatic cell count; SIL: silage; UMF: unstable milk frequency; WSP: warm-season pasture.

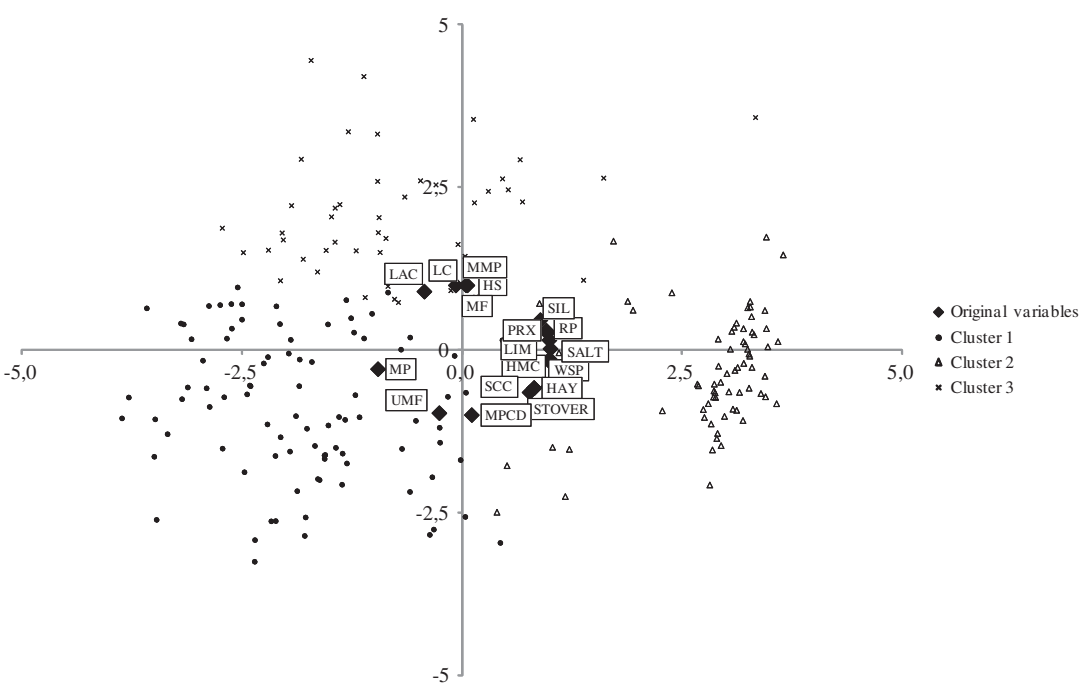

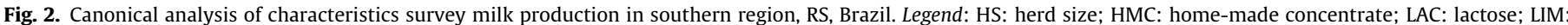

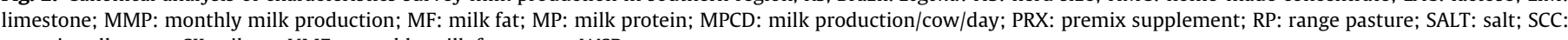
somatic cell count; SIL: silage; UMF: unstable milk frequency; WSP: warm-season pasture.

attributes. All means of characteristics related to feeding strategies were statistically different between the clusters. The average monthly milk production and number of lactating cows were statistically different between cluster 3 compared to clusters 1 and 2 , but productivity as the amount of daily milk produced did not differ between clusters. The mean observed for unstable milk frequency was different for each of the three clusters, while the milk composition and somatic cell counts were similar $(P>0.05)$ between the three clusters.

\section{Discussion}

The indicators that define the PF1 (feeding strategies) and PF2 (scale of production) coincide with those pointed out by others studies conducted in Chile (Smith et al., 2002) and Mediterranean regions (Ruiz et al., 2009) while those related to PF2 in agreement with a study carried in US (Rotz et al., 2003). Our results confirmed the large degree of diversity observed in Brazilian dairy production systems, concerning mostly feeding management and scale of production.

Table 1

Value of variables in discrimination between groups of farms from discriminant analysis in production traits of dairy production farms in the south of Brazil.

\begin{tabular}{llll}
\hline Attribute for cluster classification & Partial $R^{2}$ & $\operatorname{Pr}>F$ & $\operatorname{Pr}>$ ASCC \\
\hline Stover & 0.5198 & $<0.0001$ & $<0.0001$ \\
Limestone & 0.4457 & $<0.0001$ & $<0.0001$ \\
Premix & 0.2924 & $<0.0001$ & $<0.0001$ \\
Home-made concentrate & 0.1652 & $<0.0001$ & $<0.0001$ \\
Number of lactating cows & 0.1675 & $<0.0001$ & $<0.0001$ \\
Silage & 0.0973 & $<0.0001$ & $<0.0001$ \\
Monthly milk production & 0.0717 & 0.0005 & $<0.0001$ \\
Hay & 0.0607 & 0.0017 & $<0.0001$ \\
Range pasture & 0.0571 & 0.0026 & $<0.0001$ \\
Unstable milk frequency & 0.0416 & 0.0137 & $<0.0001$ \\
Herd size & 0.0324 & 0.0366 & $<0.0001$ \\
\hline
\end{tabular}


Table 2

Technical attributes for each cluster (mean and SD).

\begin{tabular}{|c|c|c|c|c|}
\hline \multirow[t]{2}{*}{ Attribute } & \multicolumn{4}{|l|}{ Clusters } \\
\hline & $1(n=90)$ & $2(n=74)$ & $3(n=50)$ & $P$ \\
\hline Monthly milk production (L) & $1532.93^{\mathrm{a}} \pm 1566.31$ & $1991.51^{\mathrm{a}} \pm 1707.85$ & $3622.37^{\mathrm{b}} \pm 2202.11$ & $<0.0001$ \\
\hline Milk production (L/cow/day) & $10.68 \pm 8.43$ & $10.43 \pm 7.97$ & $8.00 \pm 4.34$ & 0.2512 \\
\hline Herd size $^{a}$ & $1.04^{\mathrm{a}} \pm 0.49$ & $1.56^{\mathrm{a}} \pm 0.55$ & $2.62^{\mathrm{b}} \pm 0.45$ & $<0.0001$ \\
\hline Number of lactating cows & $6.04^{\mathrm{a}} \pm 2.96$ & $7.22^{\mathrm{a}} \pm 4.60$ & $15.87^{\mathrm{b}} \pm 19.11$ & $<0.0001$ \\
\hline Use of warm-season pasture ${ }^{\mathrm{b}}$ & $0.71^{\mathrm{a}} \pm 0.39$ & $0.33^{\mathrm{b}} \pm 0.33$ & $0.73^{\mathrm{a}} \pm 0.39$ & 0.0003 \\
\hline Use of range pasture ${ }^{\mathrm{b}}$ & $0.49^{\mathrm{a}} \pm 0.49$ & $0.37^{\mathrm{b}} \pm 0.16$ & $0.83^{\mathrm{c}} \pm 0.40$ & $<0.0001$ \\
\hline Use of silage $\mathrm{b}^{\mathrm{b}}$ & $0.26^{\mathrm{a}} \pm 0.47$ & $0.37^{\mathrm{b}} \pm 0.29$ & $0.79^{\mathrm{b}} \pm 0.43$ & $<0.0001$ \\
\hline Use of hay ${ }^{b}$ & $0.67^{\mathrm{a}} \pm 0.45$ & $0.41^{\mathrm{b}} \pm 0.41$ & $0.33^{\mathrm{c}} \pm 0.50$ & $<0.0001$ \\
\hline Use of home-made concentrate ${ }^{\mathrm{b}}$ & $0.18^{\mathrm{a}} \pm 0.36$ & $0.40^{\mathrm{b}} \pm 0.31$ & $0.24^{\mathrm{a}} \pm 0.42$ & $<0.0001$ \\
\hline Use of stover ${ }^{\mathrm{b}}$ & $0.40^{\mathrm{a}} \pm 0.40$ & $0.47^{\mathrm{b}} \pm 0.16$ & $0.57^{c} \pm 0.19$ & $<0.0001$ \\
\hline Use of salt ${ }^{\mathrm{b}}$ & $0.59^{\mathrm{a}} \pm 0.44$ & $0.33^{b} \pm 0.12$ & $0.75^{\mathrm{a}} \pm 0.40$ & $<0.0001$ \\
\hline Use of limestone ${ }^{\mathrm{b}}$ & $0.12^{\mathrm{a}} \pm 0.34$ & $0.44^{\mathrm{b}} \pm 0.23$ & $0.46^{\mathrm{c}} \pm 0.50$ & $<0.0001$ \\
\hline Use of premix ${ }^{\mathrm{b}}$ & $0.13^{\mathrm{a}} \pm 0.34$ & $0.43^{\mathrm{b}} \pm 0.25$ & $0.58^{\mathrm{c}} \pm 0.50$ & $<0.0001$ \\
\hline Average UMF ${ }^{\mathrm{C}}$ & $0.57^{\mathrm{a}} \pm 0.18$ & $0.47^{\mathrm{a}} \pm 0.19$ & $0.32^{\mathrm{b}} \pm 0.20$ & 0.0016 \\
\hline SCC $\left(10^{3}\right.$ cells $/ \mathrm{mL}$ milk $)$ & $429.54 \pm 46.46$ & $517.18 \pm 74.18$ & $353.40 \pm 75.78$ & 0.0740 \\
\hline Fat $(\%)$ & $3.43 \pm 0.41$ & $3.60 \pm 0.35$ & $3.82 \pm 0.45$ & 0.8231 \\
\hline Lactose (\%) & $4.06 \pm 0.12$ & $4.20 \pm 0.11$ & $4.55 \pm 0.11$ & 0.1308 \\
\hline Protein (\%) & $3.40 \pm 0.16$ & $3.42 \pm 0.16$ & $2.87 \pm 0.16$ & 0.1025 \\
\hline
\end{tabular}

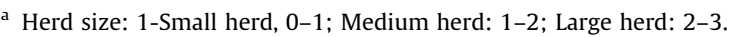

b 0 : without using in farm; 0.1 a 0.99 : eventual use in farm; 1 : using in farm.

c Value of UMF (unstable milk frequency) less than 0.5; low UMF; Value of UMF greater than 0.5; high UMF.

Smith et al. (2002) analyzed data obtained from dairy farms in the 10th Region of Chile. In their study, the first principal component is related to milk production and feeding management used in the farms and explained $24 \%$ of the variance. In other side, milk production aspects as herd size, yield per cow and total milk yield accounted for the first principal component formation while farm total surface area and applied technology level accounted in the formation of the second principal component in a study carried in U.S. (Rotz et al., 2003). With dairy goats systems, in Europe, the first two principal components were composed, respectively, by total and per animal proportions of cultivated pasture area and herd size/forage supply per goat (Ruiz et al., 2009).

García et al. (2012) assessed the characteristics of 115 dairy farmers in the Central Region of Mexico, and report that five principal factors accounted for $70.4 \%$ of the accumulated variance of the data, and the first two principal factors were characteristics of the farm (including feeding strategies) and investments in technology, somewhat similar to the results of the present study.

However, when farm conditions are not taken into consideration, as in the study conducted by Bodenmüller Filho et al. (2010), who analyzed milk samples received by dairy industries, the three first principal components consist of the nutritional quality of milk: fat, protein and total solids (PC1), sanitary quality of milk: SCC and total bacterial count (PC2) and total milk yield as PC3. PC1 and PC2 explain, respectively, $32.47 \%$ and $24.04 \%$ of the variance.

In the present study, the indicators included in the first principal factors, PF1: feeding strategies mainly represented by kind of forages and supplements used and PF2: scale of production, basically represented by herd size, number of lactating cows, total and per cow milk yields, showed considerable diversity among dairy farms. This has previously been reported in Brazilian conditions (Wagner et al., 2004; Fassio et al., 2006; Martins et al., 2007; Zanela et al., 2006) as well as in other countries (Smith et al., 2002; Ruiz et al., 2009). The scale of production's attributes (herd size, monthly milk production and number of lactating cows) were positively related to productivity, lactose concentration, and feeding strategies involving the use of silage, vitamin-mineral supplements, limestone, salt and range pasture but were slightly related to the use of home-made concentrate, which use is spread in most of dairy farms. The quantification of amount of the concen- trate offered and the constancy of its supply during the year could probably help in the differentiation of the producers, as observed by González et al. (2001) and Martins et al. (2007), who attested that the specialized production systems with high technology input provide silage and concentrate more constantly throughout the year. The use of hay, usually of low nutritional quality due to unfavorable climatic conditions at harvesting because of high rainfall and incorrect harvesting practices, and warm-season pastures, mainly characterized by low to medium quality forage but of large quantity, were associated with farms whose milk presented higher SCC, protein content and unstable milk frequency.

The association between the use of feeds with the structural aspects of the dairy farm varied accordingly to the kind of feed considered, they were very weak with the use of hay, pasture, salt and home-made concentrate (Fig. 1 shows that angles between vectors are close to $90^{\circ}$ ), meaning that dairy farms irrespective of their scale of production used those feeds. The association was positive and moderate when the use of silage and vitamin-mineral supplement was considered but the use of warm-season pastures and stover present negative association with scale of production. Moreover, we observed a strong negative correlation between production scale with the unstable milk frequency and SCC.

Although in the present study dairy farms apparently used some common feeding strategies, dairy farms with larger scale production may use larger amount of feeds that were more consistently of better quality, e.g. lower fiber content, and probably performed better milking and sanitary management with positive effects upon milk production and composition, as it was noticed by Smith et al. (2002) and Nero et al. (2009), which result in lower values for somatic cell count and unstable milk frequency, for example.

In Chile, farms producing milk with low milk ethanol-stability also fed their animals with high fiber forages, showing a negative relationship between milk instability and nutritional quality of feeds (Barchiesi-Ferrari et al., 2007). Other studies also verified a positive relation between food shortage (Zanela et al., 2006) or low quality with the frequency of ethanol-instability of milk (Marques et al., 2010; Ponce and Hernández, 2001).

Cluster 3 had the lowest average for unstable milk frequency among the three clusters, despite an unexpected stover and range pasture. Ethanol stability seemed to depend mainly on the use of 
mineral-vitamin premix, silage and commercial concentrate, higher in this cluster, since it could offset major nutritional deficiencies of cows, one of the determining factors of unstable milk frequency (Barchiesi-Ferrari et al., 2007; Lopes 2008).

The relationship between the nature and form of roughage offered to dairy cows and milk fat are described by Chilliard et al. (2001) and Couvreur and Hurtaud (2007), explaining the increase in milk fat with animals receiving high fiber content. Supply of excessively fibrous roughages reduce the intake and/or nutritional supply, causing a reduction in milk production and synthesis of its components (Sutton, 1989; Lacy Hulbert et al., 1999; NRC, 2001) although as the magnitude of reduction of the synthesis of the components is smaller compared to the reduction in milk yield, their concentration in milk, especially fat, usually increases.

In the canonical analysis, there is a difference between the 1st and 2 nd clusters from cluster 3 given by the second canonical variable related to production scale although the productivity of the three clusters have no significant differences. The first canonical variable shows, besides the differences in production scale, the differences between feeding practices. Grouping of farms according milk production and herd size (Smith et al., 2002) or by nutritional and sanitary characteristics of the milk (Bodenmüller Filho et al., 2010) was seen. In practice, the differentiation of producers according to milk yield is still the key factor for the characterization of the production unit and is often carried out by the dairy industry (Bueno et al., 2004; Wagner et al., 2004; Fassio et al., 2006; Manzano et al., 2006). However, discriminant analysis showed out the role of feeding strategies in differentiating dairy farms which is consistent with Fernandes et al. (2004) studying the same region, where those authors highlighted the lack of expertise of producers, inefficient feeding strategies and low productivity of dairy cows.

\section{Conclusions}

Feeding practices are the most important criteria for classification and grouping of the observed properties. The volume of monthly milk production differs between clusters by the number of lactating cows but not for productivity. The physical-chemical composition of milk is similar between groups. The unstable milk frequency is related to the feeding practices of each cluster.

\section{References}

Barchiesi-Ferrari, C.G., Williams-Salinas, P.A., Salvo-Garrido, S.I., 2007. Inestabilidad de la leche asociada a componentes lácteos y estacionalidad en vacas a pastoreo [Milk instability associated with milk composition and seasonal lactation in grazing dairy cows]. Pesq. Agropec. Bras. 42, 1785-1791.

Bodenmüller Filho, A., Damasceno, J.C., Previdelli, I.T.S., Santana, R.G., Ramos, C.E.C.O., Santos, G.T., 2010. Tipologia de sistemas de produção baseada nas características do leite [Typology of production systems based on the milk characteristics]. Rev, Bras. Zootec. 39, 1832-1839.

Bueno, P.R.B., Rorato, P.R.N., Dürr, J.W., Krug, E.E.B., 2004. Valor econômico para componentes do leite no Estado do Rio Grande do Sul [Economic value for milk components in the state of Rio Grande do Sul, Brazil]. Rev. Bras. Zootec. 33 (Suppl. 3), 2256-2265.

Chilliard, Y., Ferlay, A., Doreau, M., 2001. Contrôle de la qualité nutritionnelle dês matières grasses du lait par l'alimentation des vaches laitières: acides gras trans, polyinsaturés, acide linoléique conjugue [Dietary control of milk fat nutritional quali-ty in the dairy cow: trans, and polyunsatura-ted fatty acids, and conjugated linoleic acid]. INRA Prod. Anim. 14, 323-335.

Couvreur, S., Hurtaud, C., 2007. Le globule gras du lait: sécrétion, composition, fonctions et facteurs de variation [Globule milk fat: secretion, composition, function and variation factors]. INRA Prod. Anim. 20, 369-382.
Fassio, L.H., Reis, R.P., Geraldo, L.G., 2006. Desempenho técnico e econômico da atividade leiteira em Minas Gerais [Technical and economical effectiveness of milk production from Minas Gerais state, Brazil]. Cienc. Agrotec. 30, 1154-1161.

Fernandes, E.N., Bressan, M., Verneque, R.S., 2004. Zoneamento da pecuária leiteira da região sul do Brasil [Milk production mapping from Southern region in Brazil]. Cienc. Rural. 34, 485-491.

García, C.G.M., Dorward, P., Rehman, T., 2012. Farm and socio-economic characteristics of smallholder milk producers and their influence on technology adoption in Central Mexico. Trop. Anim. Health Prod. 44, 11991211.

González, F.H.D., Dürr, J.W., Fontaneli, R.S., 2001. Uso do leite para monitorar a nutrição e o metabolismo de vacas leiteiras [Use of milk for monitoring the nutrition and metabolism of lactating cows.] Gráfica UFRGS, Porto Alegre, 2001.

Lacy Hulbert, S.J., Woolford, M.W., Nicholas, G.D., Prosser, C.G., Stelwagen, K., 1999 Effect of milking frequency and pasture intake on milk yield and composition of late lactation cows. J. Dairy Sci. 82, 1232-1239.

Lopes, L.C., 2008. Composição e características físico-químicas do leite instável não ácido (LINA) na região de casa Branca, Estado de São Paulo [Composition and physical-chemical characteristics of unstable non-acid milk in the region of Casa Branca, São Paulo State]. M.SC. Dissertation, Faculdade de Zootecnia e Engenharia de Alimentos, USP, Pirassununga.

Lopes, P.F., Reis, R.P., Yamaguchi, L.C.T., 2007. Custos e escala de produção na pecuária leiteira: estudo nos principais estados produtores do Brasil [Costs and production scale in dairy farming: a study in the main producing states of Brazil]. Rev. Econ. Sociol. Rural. 45, 567-590.

Mancio, A.B., Schiffler, E.A., Lodoño Hernández, F.I. 1999. Eficiência técnica e econômica de quatro empresas de produção de leite da região de São Carlos, SP [Technical and economical evaluation of four dairy farms in São Paulo State, Brazil]. Arq. Bras. Med. Vet. Zootec. 51, 283-286.

Manzano, A., Novaes, N.J., Camargo, A.C., Esteves, S.N., Freitas, A.R., 2006. Efeitos da implantação de técnicas agropecuárias na intensificação de sistemas de produção de leite em estabelecimentos familiares [Effects of applying agricultural techniques for increase production of small family farms]. Rev. Bras. Zootec. 35, 618-628.

Marques, L.T., Fischer, V., Zanela, M.B., Ribeiro, M.E.R., Stumpf Junior, W., Manzke N., 2010. Fornecimento de suplementos com diferentes níveis de energia e proteína para vacas Jersey e seus efeitos sobre a instabilidade do leite [Supply of supplements with different levels of energy and protein to Jersey cows and their effects on milk instabilty]. Rev. Bras. Zootec. 39, 2724-2730.

Martins, P.R.G, Fischer, V., Ribeiro, M.E.R., Gomes, J.F. Stumpf Jr., W., Zanela, M.B., 2007. Produção e qualidade do leite em sistemas de produção da região leiteira de Pelotas, RS, Brasil [Milk yield and quality at production systems of the dairy region of Pelotas, RS, Brazil]. Cienc. Rural. 37, 212-217.

Nero, L.A., Viçosa, G.N., Pereira, F.E.V., 2009. Qualidade microbiológica do leite determinada por características de produção [Microbiological quality of milk determined by production characteristics]. Cienc. Tec. Alim. 29, 386-390.

National Research Council, 2001. Nutrient Requeriments of Dairy Cattle. 7th ed. National Academic Press, Washington.

Ponce, P.C., Hernández, R., 2001. Propriedades físico-químicas do leite e sua associação com transtornos metabólicos e alterações na glândula mamária [Physical and chemical properties of milk and its association with metabolic disorders and changes in the mammary gland]. In: González, F.H.D., Dürr, J.W. Fontaneli, R.S. (Eds.), Uso do leite para monitorar a nutrição e o metabolismo de vacas leiteiras. Gráfica UFRGS, Porto Alegre, pp. 61-72.

Rotz, C.A., Coiner, C.U., Soder, K.J., 2003. Automatic milking systems, farm size, and milk production. J. Dairy Sci. 86, 4167-4177.

Ruiz, F.A., Menab, Y., Castel, J.M., Guinamard, C., Bossis, N., Caramelle-Holtz, E., Contu, M.M., Sitzia, M., Fois, N., 2009. Dairy goat grazing systems in Mediterranean regions: a comparative analysis in Spain, France and Italy. Small Rum. Res. 85, 42-49.

Sas Institute Inc., 2002. Sas System for Windows 9.0. NCSU, North Carolina.

Smith, R.R., Moreira, V.L., Latrille, L.L., 2002. Caracterización de sistemas productivos lecheros en la X Región de Chile mediante análisis multivariable [Characterization of dairy productive systems in the 10th Region of Chile using multivariate analysis]. Agric. Tec. 62, 375-395.

Sutton, J.D., 1989. Altering milk composition by feeding. J. Dairy Sci. 72, 2801-2814.

Tsioulpas, A., Grandison, A.S., Lewis, M.J., 2007. Changes in physical properties of bovine milk from the colostrum period to early lactation. J. Dairy Sci. 90, 50125017.

Wagner, S.A., Gehlen, I., Wiest, J.M., 2004. Padrão tecnológico em unidades de produção familiar de leite no Rio Grande do Sul relacionado com diferentes tipologias [Tecnologies the domestic dairy producers in Rio Grande do Sul relations among the distinctive tipologies]. Cienc. Rural. 34, 1579-1584.

Zanela, M.B., Fischer, V., Ribeiro, M.E.R., Stumpf Junior, W., Zanela, C., Marques, L.T. Martins, P.R.G., 2006. Qualidade do leite em sistemas de produção na região Sul do Rio Grande do Sul [Milk quality in production systems in the Southern region of Rio Grande do Sul, Brazil]. Pesq. Agropec. Bras. 41, 153-159. 